\title{
KIR2DL1 Polymorphism Positive
}

National Cancer Institute

\section{Source}

National Cancer Institute. KIR2DL1 Polymorphism Positive. NCI Thesaurus. Code

C146646.

An indication that polymorphism of the KIR2DL1 gene has been detected in a sample. 